\title{
ASSESSMENT OF LEGUMES WITH POTENTIAL USE AS GREEN MANURE IN THE COASTAL TABLELANDS OF PIAUÍ STATE, BRAZIL ${ }^{1}$
}

\author{
MAURO SERGIO TEODORO ${ }^{2}$, KARINA NEOOB DE CARVALHO CASTRO ${ }^{2}$, JOÃO AVELAR MAGALHÃES ${ }^{2}$
}

\begin{abstract}
Green manure may lead to physical, chemical, and biological improvements to the soil. However, the information on its use in the Brazilian Northeast is scarce. The aim of this study was to assess the phenological cycle and phytomass productivity of seven legume species. This study was conducted in the second semester of 2015 in a completely randomized design with seven treatments and four replications. Plant height, fresh mass of shoot (FMS), dry mass of shoot (DMS), fresh mass of root (FMR), and dry mass of root (DMR) were determined at 100 days after sowing. Germination, flowering, and pod maturation were also assessed. The highest averages of FMS were observed in Crotalaria breviflora and Crotalaria mucronata, followed by Canavalia ensiformis, whereas the highest averages of DMS were observed in C. breviflora, $C$. ensiformis, $C$. mucronata, and Cajanus cajan cv. IAPAR 43. The highest averages of FMR were obtained by $C$. breviflora and $C$. mucronata, followed by $C$. cajan cv. Fava Larga. The species $C$. mucronata, $C$. cajan cv. IAPAR 43, and C. breviflora presented the highest averages of DMR. In addition, $C$. juncea, $C$. ensiformis, and C. cajan cv. IAPAR 43 were the earlier species regarding flowering, while C. cajan cv. Fava Larga was the later species. $C$. juncea was the earliest among all studied species regarding pod maturation. The tested legume species obtained promising initial results during the assessment period, being able to meet the expectations of biomass production and contributing to soil sustainability in this region.
\end{abstract}

Keywords: Green manure. Vegetal biomass. Coastal Tablelands of Piauí.

\section{AVALIAÇÃO DE LEGUMINOSAS COM POTENCIAL DE USO PARA ADUBOS VERDES NOS TABULEIROS LITORÂNEOS DO PIAUÍ}

\begin{abstract}
RESUMO - A adubação verde pode atribuir melhorias físicas, químicas e biológicas aos solos, porém, são escassas as informações de uso no nordeste brasileiro. Objetivou-se avaliar o ciclo fenológico e as produtividades de fitomassa de sete espécies de leguminosas. O trabalho foi conduzido durante o segundo semestre de 2015, em delineamento inteiramente casualizado, com sete tratamentos e quatro repetições. Aos 100 dias após semeadura (DAS) foram determinadas a altura das plantas, massa fresca (MFPA) e seca da parte aérea (MSPA), massa fresca (MFR) e seca da raiz (MSR). Avaliou-se também a germinação, florescimento e maturação das vagens. As maiores médias para MFPA foram obtidas pelas Crotalaria breviflora e Crotalaria mucronata, seguidas da Canavalia ensiformis. As mais produtivas para MSPA foram C. breviflora, $C$. ensiformis, C. mucronata, e Cajanus cajan Cv IAPAR 43. As maiores médias para MFR foram obtidas pelas $C$. breviflora e $C$. mucronata, seguidas do $C$. cajan $\mathrm{Cv}$ Fava Larga. A C. mucronata, $C$. cajan $\mathrm{Cv}$ IAPAR 43 e $C$. breviflora foram as espécies que obtiveram as maiores médias de MSR. A Crotalaria juncea, C. ensiformis e $C$. cajan $\mathrm{Cv}$ IAPAR 43 foram as espécies mais precoces em relação à floração, enquanto que $C$. cajan $\mathrm{Cv}$ Fava Larga foi a espécie mais tardia. C. juncea foi a mais precoce, entre todas as espécies estudadas, para a variável maturação das vagens. As espécies de leguminosas testadas obtiveram, durante o período de avaliação, resultados iniciais promissores, podendo atender as expectativas de produção de biomassa, além de contribuir para a sustentabilidade dos solos desta região.
\end{abstract}

Palavras-chave: Adubação verde. Biomassa vegetal. Tabuleiros Costeiros do Piauí.

\footnotetext{
${ }^{*}$ Corresponding author

${ }^{1}$ Received for publication in 11/11/2016; accepted in 10/23/2017.

${ }^{2}$ Embrapa meio-norte, Parnaíba, PI, Brazil; mauro-sergio.teodoro@embrapa.br _ ORCID: 0000-0002-0099-766X, karina.castro@embrapa.br - ORCID: 0000-0002-6124-0396, joao.magalhaes@embrapa.br - ORCID: 0000-0002-0270-0524.
} 


\section{INTRODUCTION}

Inappropriate modes of arable land occupation and the need for a rapid food production, coupled with economic interests in the search for profitability in the agricultural sector have contributed to the worsening of environmental degradation and increasing of these imbalances. This dynamic has caused severe changes in soil physical, chemical, and biological attributes, which, together with the acceleration of organic matter mineralization (with consequent reduction of soil fertility), have led different production systems to a decreased production potential in several regions of Brazil and world (CALEGARI, 2014). According to this author, this situation and other aspects related to climate (extreme temperatures and occurrence of floods or prolonged droughts) and the severe and unexpected attack of pests and/or diseases has caused serious risks to food security.

Despite this, modifying the technological trajectory currently dominant in the Brazilian agriculture and considerably increasing the production based on agro-ecological models of production would be possible. Several experiments demonstrate the technical, economic, and social viability of these models, contributing to the establishment of a sustainable agricultural development process (ESPÍNDOLA, 2004; ASSIS, 2005; WUTKE et al., 2007, 2008, 2009; FILHO et al., 2014).

Principles and techniques of organic agriculture are adequate for family agriculture since they contribute to its sustainability with increased opportunities, as well as providing a better nutritional quality (CAMPANHOLA; VALARINI, 2001). However, the significant growth in participation of organic agriculture in the national and international market and the dependence of its certification to standardized norms have pressured farmers in the search for organic technologies, which often lack scientific criteria or validations (PEIXOTO et al., 2008).

Organic agriculture is possible aiming only the substitution of inputs used in conventional agriculture by inputs allowed in organic agriculture. This is a product-based agriculture. On the other hand, the production of food and other agricultural products in a sustainable, economic, social, and environmental way is possible in the ecologically based agriculture. This agriculture is based on processes and seeks to intensify the free natural functions of the ecosystem (AMBROSANO et al., 2014). In this context, there is the importance of using plant species known as green manures capable of improving physical, chemical, and biological characteristics of the production environment; moreover, mineral fertilizers enriched by chemical processes and/or chemically treated to increase solubility, as well as herbicide and soil sterilizing, are prohibited in ecologically based agriculture (BRASIL, 2008).

Sandy soils of the Coastal Tablelands of Piauí State (Brazil) can be subjected to a high degree of degradation unless used and managed properly. The use of legumes for green manuring and soil cover due to its multiple uses may contribute to the preservation of agricultural soils of this region (GARCIA, 2002). The fragility of this ecosystem makes the agricultural activity of this region a challenge since there is a predominance of soils with sandy texture, low organic matter content, and low cation exchange capacity, as well as climate with high temperatures, long periods of water deficit, and constant winds (MEHL et al., 2010). In this scenario, most farmers involved with organic production acquire some inputs, including seeds of green manure, from external sources. There is a parallel market to meet these demands, which increases production costs.

Although Duque (1951) and Haynes (1970) have already mentioned the importance of legumes as a green manure for protecting and restoring soil fertility of the drought polygon and Coastal Tablelands, few studies have been conducted using these species in the Northeast region of Brazil (GARCIA, 2002). This is reflected in agricultural production units, where farmers find it difficult to adjust the use of green manures in their production systems. Knowing and adapting the use of green manuring becomes essential for recommending this management practice in the production units of this region.

Thus, this study aimed to observe the phenological cycle and assess the phytomass productivity of different legume species used as green manure in sandy soils of the Coastal Tablelands of the Piauí State, Brazil.

\section{MATERIAL AND METHODS}

This study was conducted in the second semester of 2015 at Embrapa Mid-North/UEP Parnaíba, located at the geographical coordinates $3^{\circ} 5^{\prime} \mathrm{S}$ and $41^{\circ} 46^{\prime} \mathrm{W}$ and at $46.8 \mathrm{~m}$ of altitude. Regional climate is defined as $\mathrm{C}^{2} \mathrm{dA}^{\prime} \mathrm{a}^{\prime}$ (THORNTHWAITE; MATHER, 1955), characterized as a megathermal dry sub-humid climate with small water surplus and concentration of $29.7 \%$ of potential evapotranspiration from October to December, with the averages of relative air humidity, precipitation, and temperature of $77.5 \%, 1,107 \mathrm{~mm}$, and $27.6{ }^{\circ} \mathrm{C}$, respectively (BASTOS; ANDRADE JÚNIOR; RODRIGUES, 2012).

The soil of the experimental area was described as a medium textured Dystrophic Yellow 
Latosol (Oxisol) of coastal caatinga phase (MELO et al., 2004). Soil samples from a depth of 0-20 m were collected at different points in the experimental area in order to obtain a higher uniformity of substrate. A composite sample was taken from the collected material and analyzed at the Laboratory of Water and Soil in the Embrapa Mid-North/UEP Parnaíba for soil chemical characterization (Table 1).

Table 1. Chemical characterization of the experimental area.

\begin{tabular}{ccccccccccc}
\hline $\mathrm{pH}$ & $\mathrm{P}$ & $\mathrm{K}$ & $\mathrm{Na}$ & $\mathrm{Ca}$ & $\mathrm{Mg}$ & $\mathrm{Al}$ & $\mathrm{H}+\mathrm{Al}$ & $\mathrm{N}$ & $\mathrm{OM}$ & $\mathrm{CEC}$ \\
\cline { 2 - 10 } $\mathrm{H}_{2} \mathrm{O}$ & $\mathrm{mg} / \mathrm{dm}^{3}$ & & \multicolumn{9}{c}{$\mathrm{cmol}_{\mathrm{c}} / \mathrm{dm}^{3}$} & & \multicolumn{2}{c}{$\mathrm{dag} / \mathrm{kg}$} & \\
\hline 6.38 & 15.32 & 0.23 & 0.09 & 3.90 & 0.54 & 0.03 & 1.46 & 0.05 & 1.40 & 6.13 \\
\hline
\end{tabular}

$\mathrm{P}=$ Phosphorus; $\mathrm{K}$ = Potassium; $\mathrm{Na}=$ Sodium; $\mathrm{Ca}=$ Calcium; $\mathrm{Mg}=$ Magnesium; $\mathrm{Al}=$ Aluminum; $\mathrm{H}+\mathrm{Al}=$ Potential acidity; $\mathrm{N}=$ Nitrogen; $\mathrm{OM}=$ Organic matter; $\mathrm{CEC}=$ Cation exchange capacity .

Basic information on climate is important to support irrigation planning and management and may help to study climate risk to indicate the best planting times for upland crops (BASTOS; ANDRADE JÚNIOR; RODRIGUES, 2016). Precipitation data of the experimental period were recorded by the climatological station of the Brazilian National Institute of Meteorology (INMET) located at the Experimental Field of the Embrapa Mid-North, Parnaíba, Piauí State, Brazil (Figure 1). Data regarding temperature and insolation are shown in Figures 2 and 3, respectively.

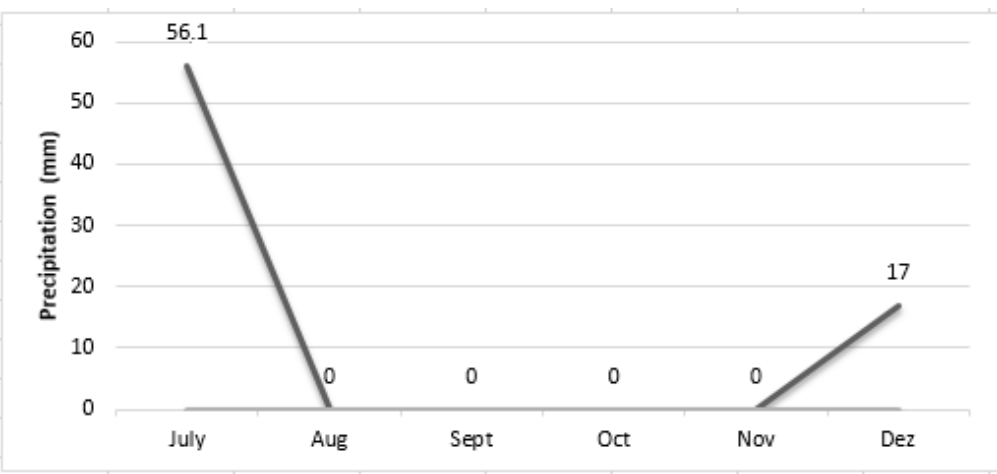

Figure 1. Average precipitation in Parnaíba, Piauí State, Brazil.

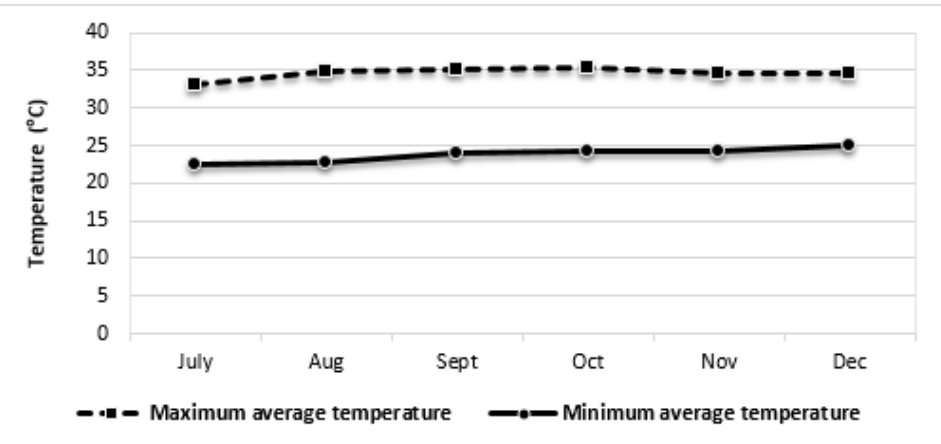

Figure 2. Average temperature in Parnaíba, Piauí State, Brazil.

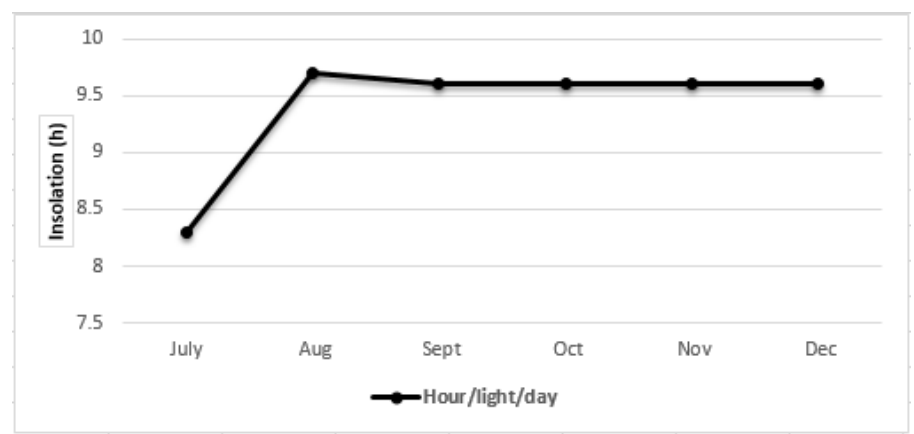

Figure 3. Average insolation in Parnaíba, Piauí State, Brazil. 
The experiment was carried out in an experimental area in which no chemical fertilization was used in the last five years. Soil tillage consisted of a plowing and surface harrowing with subsequent leveling, followed by manual leveling.

The experimental design was a completely randomized design with seven treatments and four replications in plots of $2.0 \times 2.0 \mathrm{~m}$ containing five rows of plants spaced $0.50 \mathrm{~m}$. A high seed density (approximately twice the number of seeds corresponding to each treatment) was used. Plant population was subsequently adjusted by thinning at 20 days after sowing (DAS) (Table 2). Two manual weedings were carried out. The irrigation system used was a conventional sprinkling with a two-day irrigation shift and an average duration of 1.0 hour.

Table 2. Spacing and sowing density of plants used as green manure.

\begin{tabular}{lccc}
\hline \multicolumn{1}{c}{ Common name } & Depth (cm) & Spacing (m) & seeds/linear meter \\
\hline Shortflower rattlebox & 2 to 3 & 0.50 & 30 to $35^{*}$ \\
Sunn hemp & 2 to 3 & 0.50 & 22 to $27^{*}$ \\
Smooth rattlebox & 2 to 3 & 0.50 & 40 to $45^{*}$ \\
Jack bean & 2 to 5 & 0.50 & 4 to $5^{*}$ \\
Pigeonpea cv. Fava Larga & 2 to 3 & 0.50 & 20 to $25^{*}$ \\
Dwarf pigeonpea cv. IAPAR 43 & 2 to 3 & 0.50 & 20 to $25^{*}$ \\
White hoarypea & 2 to 3 & 1.00 & $5^{* *}$ \\
\hline
\end{tabular}

*Piraí Sementes. **(FILHO et al., 2014).

The annual species of tropical climate used in the treatments were $\mathrm{T} 1$ - dwarf pigeonpea cv. IAPAR 43 (Cajanus cajan); T2 - smooth rattlebox (Crotalaria mucronata); T3 - sunn hemp (Crotalaria juncea); T4 - jack bean (Canavalia ensiformis L.); T5 - shortflower rattlebox (Crotalaria breviflora); and T6 - pigeonpea cv. Caqui/Fava Larga (Cajanus cajan). Moreover, the perennial species of tropical climate T7 - white hoarypea (Tephrosia candida) was also used.

All the treatments were cut at $0.05 \mathrm{~m}$ above soil surface by using a pruning shears at 100 days after test installation. The useful plot consisted of the central rows, discarding the borders, totaling an area of $0.5 \mathrm{~m}^{2}$ (1.00 m linear $\times 0.5 \mathrm{~m}$ between rows $)$. Plant roots were also removed from a depth of 0.20 $\mathrm{m}$ by using a mattock in order to obtain fresh and dry biomass for all the species used in this study. Plant height (PH), fresh mass of shoot (FMS), dry mass of shoot (DMS), fresh mass of root (FMR), and dry mass of root (DMR) were determined. Plants were considered under full flowering when they reached $50 \%$ of flowering.

All the botanical material from shoot and root was weighed on a precision scale to obtain the fresh biomass (FMS and FMR). Subsequently, this material was placed in paper bags and conditioned in a forced ventilation oven at $65{ }^{\circ} \mathrm{C}$ for 48 hours until constant weight to determine dry biomass production (DMS and DMR).

The data were submitted to analysis of variance by using the software ASSISTAT and Duncan's test at 5\% probability level was applied for the contrast of means.

\section{RESULTS AND DISCUSSION}

Table 3 shows the data related to the averages of emergence (E), flowering (F), plant height at flowering (PHF), and pod maturation (PM). No significant differences were observed regarding the emergence of all the studied treatments. The results obtained for C. juncea (T3), C. ensiformis (T4), and C. cajan cv. IAPAR 43 (T1) showed precocity in relation to flowering when compared to other regions of Brazil. In addition, no significant differences were observed between these plants $(\mathrm{p}<0.05)$. In our study, the flowering of $C$. juncea, $C$. ensiformis, and C. cajan cv. IAPAR 43 started between 66 and 75 DAS. However, the company Piraí Sementes, specialized in commercializing green manure seeds, presents as a reference for this variable 90 to 120 DAS in south-central Brazil (PIRAÍ SEMENTES, 2014).

In the Coastal Tablelands of Piauí State, Garcia (2002) observed a period of 52 and 75 DAS for the beginning of flowering and the full flowering of C. ensiformis, respectively, whereas, for $T$. candida, these periods were 120 and 170 DAS, respectively. On the other hand, the company Piraí Sementes presents as a flowering reference for $C$. breviflora a period from 90 to 120 DAS (PIRAÍ SEMENTES, 2014). In addition, no significant differences $(p>0.05)$ were observed between the other species of this study, which presented values of 92 DAS for $C$. mucronata (T2), 111 DAS for $C$. breviflora (T5), 154 DAS for $C$. cajan cv. Fava Larga (T6), and 166 DAS for T. candida (T7). 
M. S. TEODORO et al.

Table 3. Phenological data of different legume species for green manuring.

\begin{tabular}{ccccc}
\hline Species & $\begin{array}{c}\text { Emergence } \\
\text { (DAS) }\end{array}$ & Flowering (DAS) & Plant height at flowering (m) & $\begin{array}{c}\text { Pod maturation } \\
\text { (DAS) }\end{array}$ \\
\hline T1 & $4 \mathrm{a}$ & $75.00 \mathrm{~d}$ & $1.21 \mathrm{bc}$ & $97.75 \mathrm{e}$ \\
$\mathrm{T} 2$ & $4 \mathrm{a}$ & $92.00 \mathrm{c}$ & $1.33 \mathrm{ab}$ & $105.25 \mathrm{e}$ \\
$\mathrm{T} 3$ & $2 \mathrm{a}$ & $66.75 \mathrm{~d}$ & $1.58 \mathrm{a}$ & $77.25 \mathrm{f}$ \\
$\mathrm{T} 4$ & $5 \mathrm{a}$ & $70.25 \mathrm{~d}$ & $0.89 \mathrm{~d}$ & $133.75 \mathrm{c}$ \\
$\mathrm{T} 5$ & $4 \mathrm{a}$ & $111.25 \mathrm{~b}$ & $0.97 \mathrm{~cd}$ & $120.50 \mathrm{~d}$ \\
T6 & $4 \mathrm{a}$ & $154.25 \mathrm{a}$ & $1.54 \mathrm{a}$ & $161.25 \mathrm{~b}$ \\
T7 & $5 \mathrm{a}$ & $166.50 \mathrm{a}$ & $0.97 \mathrm{~cd}$ & $180.25 \mathrm{a}$ \\
\hline $\mathrm{CV}(\%)$ & 25.0 & 8.33 & 16.04 & 5.79 \\
\hline
\end{tabular}

Means followed by the same letter in the column do not differ statistically by Duncan's test at $5 \%$ level.

DAS - days after sowing.

Mascarenhas and Wutke (2014) consider temperature, water availability, and photoperiod, together with biotic and soil fertility factors, as the most restrictive to green manure cultivation. However, in the tropics, where there is rarely a lack of solar radiation, the effects of light on plant development are very little evident (ALCÂNTARA; BUFARAH, 1992). The variation in day and night length throughout the year is an important conditioning characteristic of vegetative development and induction to flowering, especially in legumes. Thus, the critical length of day or night is an inductive factor of change from the vegetative to reproductive or flowering phases (MASCARENHAS; WUTKE, 2014). This phenomenon may have influenced the results obtained for flowering in our study.

The cycle of $C$. juncea is dependent on photoperiod variation, but this species is one of the less sensitive of this botanical genus (AMABILE; FANCELLI; CARVALHO, 2000; CARVALHO; AMABILE, 2006). Pigeonpea is usually sensitive to photoperiod, with a quantitative response to flowering on short days and influenced by thermosperiod (MASCARENHAS; WUTKE, 2014), while jack bean has no sensitivity to photoperiod and are appropriately used in the semiarid region of Northeast Brazil (BURLE et al., 2006; CALEGARI et al., 1993; CARVALHO; AMABILE, 2006).

Regarding plant height, C. juncea (T3), $C$. cajan cv. Fava Larga (T6), and C. mucronata (T2) obtained the highest averages, with values of 1.58 , 1.54 , and $1.33 \mathrm{~m}$, respectively, and no significant differences $(\mathrm{p}<0.05)$ between plants. The species $C$. cajan cv. IAPAR 43 (T1), presented an average height of $1.21 \mathrm{~m}$, differing statistically from the species $C$. breviflora (T5), T. candida (T7), and $C$. ensiformis (T4), with averages of $0.97,0.97$, and $0.89 \mathrm{~m}$, respectively. Calegari and Donizete Carlos (2014) assessed 120- to 180-day-old plants and observed heights from 2.0 to $3.0 \mathrm{~m}$ for $C$. juncea, 1.5 to $2.0 \mathrm{~m}$ for $C$. mucronata, 2.0 to $3.0 \mathrm{~m}$ for $C$. cajan cv. Fava Larga, 1.0 to $1.5 \mathrm{~m}$ for $C$. cajan cv. IAPAR $43,0.8$ to $1.0 \mathrm{~m}$ for $C$. breviflora, 1.2 to $2.5 \mathrm{~m}$ for $T$. candida, and 0.8 to $1.0 \mathrm{~m}$ for $C$. ensiformis.

A significant difference $(\mathrm{p}>0.05)$ was observed for PM. The species C. juncea (T3) was the earliest, with an average of 77.25 DAS, differing statistically from all other legume species, followed by $C$. ensiformis cv. IAPAR 43 (T1) and $C$. mucronata (T2), with no significant differences between them (97.75 and 105.25 DAS, respectively). In addition, the species $C$. breviflora (T5), $C$. ensiformis (T4), and C. cajan cv. Fava Larga (T6) presented averages of $120.50,133.75$, and 161.25, respectively. The species with later pod maturation was $T$. candida (T7), with a value of 180.25 DAS. In an experiment conducted in the Coastal Tablelands, Garcia (2002) observed a period for the beginning of pod maturation of 130 DAS for $C$. ensiformis and 160 DAS for $T$. candida.

Table 4 shows the results of FMS, DMS, FMR, and DMR. Significant differences $(p>0.05)$ were observed considering the production performance of the studied legumes. The species yielding the highest fresh mass were $C$. breviflora (T5) and C. mucronata (T2), with no significant differences between them, followed by $C$. ensiformis (T4). On the other hand, those species with the lowest fresh mass were C. cajan cv. IAPAR 43 (T1) and C. cajan cv. Fava Larga (T6), with no differences between them, followed by $C$. juncea (T3) and T. candida (T7), respectively. 
M. S. TEODORO et al.

Table 4. Average productivity of fresh and dry mass of different legume species used as green manure.

\begin{tabular}{ccccc}
\hline Species & FMS (t/ha) & DMS (t/ha) & FMR (t/ha) & DMR (t/ha) \\
\hline T1 & $25.45 \mathrm{~cd}$ & $13.25 \mathrm{ab}$ & $3.00 \mathrm{bc}$ & $2.00 \mathrm{ab}$ \\
T2 & $51.50 \mathrm{ab}$ & $13.50 \mathrm{ab}$ & $5.20 \mathrm{ab}$ & $2.20 \mathrm{a}$ \\
T3 & $14.35 \mathrm{~d}$ & $9.80 \mathrm{~b}$ & $3.00 \mathrm{bc}$ & $1.70 \mathrm{~b}$ \\
T4 & $40.40 \mathrm{bc}$ & $14.55 \mathrm{ab}$ & $0.70 \mathrm{c}$ & $0.51 \mathrm{c}$ \\
T5 & $63.10 \mathrm{a}$ & $21.75 \mathrm{a}$ & $5.62 \mathrm{a}$ & $1.95 \mathrm{ab}$ \\
T6 & $27.50 \mathrm{~cd}$ & $12.20 \mathrm{~b}$ & $4.74 \mathrm{ab}$ & $1.55 \mathrm{~b}$ \\
T7 & $17.85 \mathrm{~d}$ & $7.25 \mathrm{~b}$ & $1.35 \mathrm{c}$ & $0.92 \mathrm{c}$ \\
\hline CV $(\%)$ & 36.85 & 42.55 & 32.46 & 22.43 \\
\hline
\end{tabular}

Means followed by the same letter in the column do not differ statistically by Duncan's test at $5 \%$ level.

Phytomass production of C. breviflora (T5) was higher when compared to the other species assessed in the same period, with a value of $63.1 \mathrm{t} \mathrm{ha}^{-1}$, but without statistical differences from $C$. mucronata (T2), which presented a value of $51.5 \mathrm{t} \mathrm{ha}{ }^{-1}$. Fresh biomass production of $C$. ensiformis (T4) was $40.40 \mathrm{t} \mathrm{ha}^{-1}$. No significant differences $(\mathrm{p}<0.05)$ was observed between fresh phytomass production for $C$. cajan $\mathrm{cv}$. IAPAR 43 (T1) (25.45 $\left.\mathrm{t} \mathrm{ha}^{-1}\right)$, C. cajan cv. Fava Larga (T6) (27.5 $\left.\mathrm{t} \mathrm{ha}^{-1}\right)$, and T. candida (T7) (17.85 $\left.\mathrm{t} \mathrm{ha}^{-1}\right)$.

C. breviflora is a native and endemic species of Brazil, being resistant to drought, which may explain its fresh mass productivity. However, the contrast of phytomass production among the crotalaria species causes a great impact. The lowest productivity was obtained by $C$. juncea, with a value of $14.35 \mathrm{t} \mathrm{ha}^{-1}$, a species considered as productive or recommended by its productivity in vegetal biomass, producing from 15 to $60 \mathrm{t} \mathrm{ha}^{-1}$ of fresh mass (WUTKE; CALEGARI; WILDNER, 2014).

Crotalaria species are annual plants, very well adapted to sandy textured soils with a low fertility (WUTKE; CALEGARI; WILDNER, 2014). Although the Coastal Tablelands soils present these characteristics, factors such as temperature, water availability, and photoperiod should be taken into consideration in order to obtain an adequate development and more efficient utilization in the different production systems (MASCARENHAS; WUTKE, 2014). According to these authors, although there are few studies on water stress in green manures, particularly in legumes, quantity and distribution of water are decisive factors for plant development, particularly in autumn/winter in regions without precipitation.

In experiments conducted in the Cerrado biome in Goiás State, Amabile, Fancelli and Carvalho (2000) observed an interaction between seasons and species on fresh phytomass production when changed periods from one considered as favorable (beginning of November) to others considered as marginal (January and March), decreasing vegetative stage in species such as $C$. ochroleuca, C. juncea, and C. cajan. The authors concluded that the delay in sowing time resulted in a linear reduction of fresh mass production for the studied species.

Phytomass production of jack bean was higher than in other studies (WUTKE; CALEGARI; WILDNER, 2014; OLIVEIRA et al., 2013; TEIXEIRA et al., 2005), proving that, despite a slow initial growth, this species has characteristics which make it adapted for the conditions of this test, including a deep root system, which confers resistance to drought (WUTKE; CALEGARI; WILDNER, 2014). For pigeonpea cultivars, the results corroborate with those obtained by other authors (WUTKE; CALEGARI; WILDNER, 2014), who described the pigeonpea as a species with a vigorous, well developed and deep root system, giving the plant resistance in long periods of drought, such as those faced during the development of this study.

Regarding shoot dry mass, significant differences $(p>0.05)$ were observed between the studied legumes. The species with the highest dry mass were $C$. breviflora (T5), $C$. ensiformis (T4), $C$. mucronata (T2), and C. cajan cv. IAPAR 43 (T1), with values of $21.75,14.55,13.50$, and $13.25 \mathrm{t} \mathrm{ha}^{-1}$, respectively, with no significant differences between them. On the other hand, those with the lowest values of dry mass of shoot were $C$. cajan cv. Fava Larga (T6), C. juncea (T3), and T. candida (T7), with values of $12.2,9.8$, and $7.25 \mathrm{tha}^{-1}$, respectively, with no significant differences between them. Moreover, the species C. breviflora stood out and presented the highest average of dry mass production when compared to the other species. However, all the studied species presented higher values when compared to those observed by Wutke, Calegari and Wildner (2014) and Amado et al. (2014), under the no-tillage system, and Garcia (2002), under similar edaphoclimatic conditions. In this case, the only exception was observed for $C$. juncea probably due to the climatic factors observed during the experimental period of our study. Garcia (2002) recommends the use of perennial species just as $T$. candida for green manure in later phenological stages, since it may maximize phytomass production because this plant can produce annually about 6 to $8 \mathrm{t} \mathrm{ha}^{-1}$ of dry mass (CALEGARI; DONIZETI 
CARLOS, 2014).

Significant differences $(p>0.05)$ were observed between the studied species regarding the root fresh-mass production. The legume species with the highest values of FMR were C. breviflora (T5), C. mucronata (T2), and C. cajan cv. Fava Larga (T6), with values of 5.62, 5.2, and $4.74 \mathrm{t} \mathrm{ha}^{-1}$, respectively, and no significant differences between them. The species $C$. juncea (T3) and $C$. cajan cv. IAPAR 43 (T1) showed no differences differ from one another, with both values of $3.0 \mathrm{t} \mathrm{ha}^{-1}$. On the contrary, the lowest values of FMR were obtained for $C$. ensiformis (T4) $\left(0.70 \mathrm{t} \mathrm{ha}^{-1}\right)$ and $T$. candida (T7) (1.35 $\left.\mathrm{t} \mathrm{ha}^{-1}\right)$.

The highest averages of production of DMR were obtained by C. mucronata (T2), C. cajan cv. IAPAR 43 (T1), and $C$. breviflora (T5), with values of $2.2,2.0$, and $1.95 \mathrm{t} \mathrm{ha}^{-1}$, respectively, with no significant differences $(\mathrm{p}>0.05)$ between them. The species $C$. juncea (T3) and C. cajan cv. Fava Larga (T6) had no differences from one another, with DMR values of 1.7 and $1.55 \mathrm{t} \mathrm{ha}^{-1}$, respectively. On the other hand, the lowest values were observed for $T$. candida (T7) and C. ensiformis (T4), with values of 0.92 and $0.51 \mathrm{t} \mathrm{ha}^{-1}$, respectively. In our study, plant roots were manually removed at a depth of up to $20 \mathrm{~cm}$ to obtain the fresh and dry mass. According to Calegari et al. (1992), the data on root production may be underestimated due to the difficulty in collecting the entire root system mainly because some legumes can penetrate several meters deep in the soil. However, the quantification of this attribute is valid because it is rarely accounted for in production systems using the green manure management. Wutke, Bulisani and Mascarenhas (1993) described the development of $C$. juncea roots at depths of up to $4.5 \mathrm{~m}$ at 130 days of age, with $79 \%$ of its weight within the first $30 \mathrm{~cm}$. In spite of this possibility, an average of $1.7 \mathrm{t} \mathrm{ha}^{-1}$ of DMR for $C$. juncea was obtained in our study, which is higher than the value reported by Espíndola et al. (1998), who obtained a production of $0.57 \mathrm{t} \mathrm{ha}^{-1}$ of DMR for the same species.

In this study, we searched for a more detailed knowledge of some plants used as green fertilizers and their regional adaptation, where few research results are available for the Brazilian Northeast. This is not the end of the issue; there is still a need for continuity of research on green manuring aiming at recommendations of this management practice in the region's production units.

\section{CONCLUSIONS}

Under sandy soil conditions in the region of the Coastal Tablelands of Piaui State, the tested legume species showing the highest production of fresh mass during the experimental period and under local conditions were $C$. breviflora $\left(63 \mathrm{tha}^{-1}\right)$ and $C$. mucronata $\left(51 \mathrm{t} \mathrm{ha}^{-1}\right)$, followed by $C$. ensiformis $\left(40 \mathrm{t} \mathrm{ha}^{-1}\right)$. In addition, the highest production of dry mass was obtained for C. breviflora $\left(21.7 \mathrm{t} \mathrm{ha}^{-1}\right)$.

\section{ACKNOWLEDGEMENTS}

To the colleagues Francisco José do Nascimento and Bernardo Alves for all the support in the field and to the interns Taline, Roberta, Rayara, Maria de Fátima, Raimunda, Isaias, Jéssica, Laura, Mayara, and Lucas, undergraduate students of Agronomy in the UESPI, Campus of Parnaíba, Piauí State, Brazil.

\section{REFERENCES}

ALCÂNTARA, P. B.; BUFARAH, G. Plantas forrageiras: gramíneas \& leguminosas. 4. ed. rev. São Paulo, SP: Nobel, 1992. 162 p.

AMABILE, R. F.; FANCELLI, A. L.; CARVALHO, A. M. Comportamento de espécies de adubos verdes em diferentes épocas de semeadura e espaçamentos na região dos Cerrados. Pesquisa Agropecuária Brasileira, Brasília, v. 35, n. 1, p. 47-54, 2000.

AMADO, T. J. C. et al. Adubação verde na produção de grãos e no sistema de plantio direto. In: FILHO, O. F. L. et al. (Eds.). Adubação Verde e plantas de cobertura no Brasil: fundamentos e prática. Brasília: Embrapa, 2014. v. 2, cap. 16, p. 81-125.

AMBROSANO, E. J. et al. Adubação verde na agricultura orgânica. In: FILHO, O. F. L. et al. (Eds.). Adubação Verde e plantas de cobertura no Brasil: fundamentos e prática. Brasília: Embrapa, 2014. v. 2, cap. 15 , p. 45-80.

ASSIS, R. L. Agroecologia: Visão histórica e perspectivas no Brasil. In: AQUINO, A. M.; ASSIS, R. L. (Eds.). Agroecologia: Princípios e técnicas para uma agricultura orgânica sustentável. Brasília: Embrapa, 2005. cap. 7, p. 173-182.

BASTOS, E. A.; ANDRADE JÚNIOR, A. S.; RODRIGUES, B. H. N. Boletim agrometeorológico de 2011 para o município de Parnaíba, Piauí. Teresina: Embrapa Meio-Norte, 2012. 37 p. (Documentos, 221).

BASTOS, E. A.; ANDRADE JÚNIOR, A. S.; RODRIGUES, B. H. N. Boletim agrometeorológico de 2015 para o município de Parnaíba, Piauí. Teresina: Embrapa Meio-Norte, 2016. 38 p. (Documentos, 240).

BRASIL. Ministério da Agricultura, Pecuária e 
Abastecimento. Instrução Normativa n. 64 de 18 de dezembro de 2008. Aprova o regulamento técnico para os sistemas orgânicos de produção animal e vegetal e as listas de substâncias permitidas para uso nos Sistemas Orgânicos de Produção animal e vegetal. Diário Oficial [da] República Federativa do Brasil. Brasília, 19 dez. 2008c. Seção 1, p. 21-26. Accessed on Jul. 2016.

BURLE, M. L. et al. Caracterização das espécies de adubo verde. In: CARVALHO, A. M.; AMABILE, R. F. (Eds.). Cerrado: adubação verde. Planaltina, DF: Embrapa Cerrados, 2006. p. 71-142.

CALEGARI, A. Perspectivas e estratégias para a sustentabilidade e o aumento da biodiversidade dos sistemas agrícolas com o uso de adubos verdes. In: FILHO, O. F. L. et al. (Eds.). Adubação Verde e plantas de cobertura no Brasil: fundamentos e prática. Brasília: Embrapa, 2014. v. 1, cap. 1, p. 21 36.

CALEGARI, A.; DONIZETI CARLOS, J. A. Recomendações de plantio e informações gerais sobre o uso de espécies para adubação verde no Brasil. In: FILHO, O. F. L. et al. (Eds.). Adubação Verde e plantas de cobertura no Brasil: fundamentos e prática. Brasília: Embrapa, 2014. v. 2, cap. 27, p. $451-478$.

CALEGARI, A. et al. Aspectos gerais da adubação verde. In: COSTA, M. B. B. (Ed.). Adubação verde no sul do Brasil. Rio de Janeiro: AS-PTA, 1992. p. $1-55$

CALEGARI, A. et al. Caracterização das principais espécies de adubo verde. In: COSTA, M. B. B. (Ed.). Adubação verde no Sul do Brasil. Rio de Janeiro: AS-PTA, 1993. p. 205-327.

CAMPANHOLA, C.; VALARINI P. J. A agricultura orgânica e seu potencial para o pequeno agricultor. Cadernos de Ciência \& Tecnologia. Brasília, v. 18, n. 3, p. $69-101,2001$

CARVAlHO, A. M.; AMABILE, R. F. Cerrado: adubação verde. Planaltina, DF: Embrapa Cerrados, 2006. 369 p.

DUQUE, J. G. Solo e água no polígono das secas. Fortaleza, CE: DNOCS, 1951. 250 p.

ESPÍNDOLA, J. A. A. Estratégias para utilização de leguminosas para adubação verde em unidades de produção agroecológica. Seropédica: Embrapa Agrobiologia, 2004. 24 p. (Embrapa Agrobiologia. Documentos, 174).

ESPÍNDOLA, J. A. A. et al. Influência da adubação verde na colonização micorrízica e na produção da batata-doce. Pesquisa Agropecuária Brasileira, Brasília, v. 24, n. 2, p. 339-347, 1998

FILHO, O. F. L. et al. Adubação Verde e plantas de cobertura no Brasil: fundamentos e prática. 1. ed. Brasília, DF: EMBRAPA, 2014. v. 1. 507 p.

GARCIA, L. F. Introdução e avaliação de leguminosas para adubação verde em solos arenosos de Tabuleiros Costeiros do Piauí. Revista da Faculdade de Agronomia, Maracay, v. 28, n. 2, p. 93-103. 2002.

HAYNES, J. L. Uso agrícola dos tabuleiros costeiros do Nordeste do Brasil: um exame das pesquisas. 2. ed. Recife, PE: SUDENE, 1970. 139 p.

MASCARENHAS, H. A. A.; WUTKE, E. B. Adubação, nutrição e fatores climáticos limitantes ao desenvolvimento dos adubos verdes. 2014. In: FILHO, O. F. L. et al. (Eds.). Adubação Verde e plantas de cobertura no Brasil: fundamentos e prática. Brasília: Embrapa, 2014. v. 1, cap. 5, p. 189 224

MEHL, H. U. et al. Produção de biomassa e padrão de decomposição de adubos verdes cultivados nas entrelinhas de acerola orgânica. In: REUNIÃO BRASILEIRA DE MANEJO E CONSERVAÇÃO DO SOLO E DA ÁGUA, 18., 2010, Teresina. Anais... Teresina: CPAMN: UFPI, 2010. 4 p. 1 CDROM.

MELO, F. B. et al. Levantamento Detalhado dos Solos da Área da Embrapa Meio-Norte/UEP de Parnaíba. Teresina: Embrapa Meio-Norte, 2004. 22 p. (Documentos, 89).

OLIVEIRA, T. C. T. et al. Produção de biomassa fresca e seca por diferentes leguminosas no Submédio São Francisco. In: CONGRESSO BRASILEIRO DE AGROECOLOGIA, 8., 2013, Porto Alegre. Anais... Brasília: Cadernos de Agroecologia, 2013. v. 8, n. 2, 5 p.

PEIXOTO, R. T. G. et al. Cenários e Ações na Pesquisa Federal em Agricultura Orgânica no Brasil. Rio de Janeiro: Embrapa Agrobiologia, 2008. 44 p. (Documentos, 257).

PIRAÍ SEMENTES. Adubação verde e cobertura vegetal. Disponível em: <http://www.pirai.com.br>. Acesso em: 02 jan. 2014.

TEIXEIRA, C. M. et al. Produção de biomassa e teor de macronutrientes do milheto, feijão de porco e guandu anão em cultivo solteiro e consorciado. Ciência e Agrotecnologia, Lavras, v. 29, n. 1, p. 93 99, 2005. 
THORNTHWAITE, C. W.; MATHER, J. R. The water balance. Centerton: Drexel Institute of technology, 104 p. (Drexel Institute of technology. Publication in climatology, v. 8, n. 1). 1955.

WUTKE, E. B.; BULISANI, E. A.; MASCARENHAS, H. A. A. I Curso Sobre Adubação Verde no Instituto Agronômico. Campinas: Instituto Agronômico de Campinas, 1993. 121 p. (Documentos IAC, $\mathrm{n}^{\mathrm{o}} 35$ ).

WUTKE, E. B.; CALEGARI, A.; WILDNER, L. P. Espécies de adubos verdes e plantas de cobertura e recomendações para uso. In: FILHO, O. F. L. et al. (Eds.). Adubação Verde e plantas de cobertura no Brasil: fundamentos e prática. Brasília: Embrapa, 2014. v. 1, cap. 3, p. 59-167.

WUTKE, E. B. et al. Bancos comunitários de sementes de adubos verdes: informações técnicas. Brasília, DF: Ministério da Agricultura, Pecuária e Abastecimento, 2007. 52 p.

WUTKE, E. B. et al. Leguminosas alimentícias e adubos verdes. In: ALBUQUERQUE, A. C. S.; SILVA, A. G. (Eds.). Agricultura tropical: quatro décadas de inovações tecnológicas, institucionais e políticas. Brasília, DF: Embrapa Informação Tecnológica, 2008. v. 1, p. 251-274.

WUTKE, E. B. et al. Adubação verde no Estado de São Paulo. Campinas: CATI, 2009. 89 p. (CATI. Boletim técnico, 249). 